\title{
Article
}

\section{Design of All-Small-Molecule Organic Solar Cells Approaching 14\% Efficiency via Isometric Terminal Alkyl Chain Engineering}

\author{
Haiyan Chen ${ }^{1,2,3}$, Hua Tang 2,3, Dingqin $\mathrm{Hu}{ }^{1,2,3, *}$, Yiqun Xiao ${ }^{4}$, Jiehao $\mathrm{Fu}^{2}$, Jie $\mathrm{Lv}^{2,3}$, Qingqing Yu ${ }^{2,3}$, \\ Zeyun Xiao ${ }^{1,2,3}$, Xinhui $\mathrm{Lu}^{4, *}$, Hanlin $\mathrm{Hu}^{5, *}$ and Shirong $\mathrm{Lu}^{1,2,3, *}$ \\ 1 Chongqing University, 174 Shazhengjie, Shapingba, Chongqing 400044, China; chenhaiyan@cigit.ac.cn (H.C.); \\ xiao.z@cigit.ac.cn (Z.X.) \\ 2 Chongqing Institute of Green and Intelligent Technology, Chinese Academy of Sciences, Chongqing 400714, \\ China; tanghua@cigit.ac.cn (H.T.); 20113853r@connect.polyu.hk (J.F.); lvjie@cigit.ac.cn (J.L.); \\ yuqingqing@cigit.ac.cn (Q.Y.) \\ 3 Chongqing School, University of Chinese Academy of Sciences, Chongqing 400714, China \\ 4 Department of Physics, The Chinese University of Hong Kong, Shatin, New Territories, Hong Kong, China; \\ xiaoyiqun12@gmail.com \\ 5 Hoffman Institute of Advanced Materials, Shenzhen Polytechnic, 7098 Liuxian Boulevard, Shenzhen 518055, China \\ * Correspondence: hudingqin@cigit.ac.cn (D.H.); xinhui.lu@cuhk.edu.hk (X.L.); hanlinhu@szpt.edu.cn (H.H.); \\ lushirong@cigit.ac.cn (S.L.)
}

check for

updates

Citation: Chen, H.; Tang, H.; Hu, D.; Xiao, Y.; Fu, J.; Lv, J.; Yu, Q.; Xiao, Z.; $\mathrm{Lu}, \mathrm{X}$; Hu, H.; et al. Design of All-Small-Molecule Organic Solar Cells Approaching 14\% Efficiency via Isometric Terminal Alkyl Chain Engineering. Energies 2021, 14, 2505. https://doi.org/10.3390/en14092505

Academic Editor: Sanjay

Gopal Ullattil

Received: 18 March 2021

Accepted: 22 April 2021

Published: 27 April 2021

Publisher's Note: MDPI stays neutral with regard to jurisdictional claims in published maps and institutional affiliations.

Copyright: (c) 2021 by the authors. Licensee MDPI, Basel, Switzerland. This article is an open access article distributed under the terms and conditions of the Creative Commons Attribution (CC BY) license (https:/ / creativecommons.org/licenses/by/ $4.0 /)$.
Abstract: Morphology is crucial to determining the photovoltaic performance of organic solar cells (OSCs). However, manipulating morphology involving only small-molecule donors and acceptors is extremely challenging. Herein, a simple terminal alkyl chain engineering process is introduced to fine-tune the morphology towards high-performance all-small-molecule (ASM) OSCs. We successfully chose a chlorinated two-dimension benzo[1,2-b:4,5- $\left.\mathrm{b}^{\prime}\right]$ dithiophene (BDT) central unit and two isomeric alkyl cyanoacetate as the end-capped moieties to conveniently synthesize two isomeric small-molecule donors, namely, BT- $\mathrm{R}_{\mathrm{O}}-\mathrm{Cl}$ and $\mathrm{BT}-\mathrm{R}_{\mathrm{EH}}-\mathrm{Cl}$, each bearing linear n-octyl $(\mathrm{O})$ as the terminal alkyl chain and another branched 2-ethylhexyl (EH) as the terminal alkyl chain. The terminal alkyl chain engineering process provided BT- $\mathrm{R}_{\mathrm{O}}-\mathrm{Cl}$ with $13.35 \%$ efficiency and BT- $\mathrm{R}_{\mathrm{EH}}-\mathrm{Cl}$ with $13.90 \%$ efficiency ASM OSCs, both with Y6 as the electron acceptor. The successful performance resulted from uniform phase separation and the favorable combination of face-on and edge-on molecular stacking of blended small-molecule donors and acceptors, which formed a fluent 3D transport channel and thus delivered high and balanced carrier mobilities. These findings demonstrate that alkyl chain engineering can finely control the morphology of ASM OSCs, and provides an alternative for the optimal design of small-molecule materials towards high-performance ASM OSCs.

Keywords: organic solar cell; small-molecule donor; alkyl chains; morphology

\section{Introduction}

Organic solar cells (OSCs) are recognized as a competitive system of photovoltaic application, due to their superior characteristics, including light weight, flexibility, low-cost solution preparation, and roll-to-roll fabrication [1]. During the past decade, research on OSCs and related photovoltaic materials has resulted in significant improvements to device performance [2-4]. In the past five years, the power conversion efficiency (PCE) of acceptor-donor-acceptor (A-D-A)-type small-molecule-based OSCs has seen continuous improvement, especially the community of polymer donors and non-fullerene acceptors (NFAs). A large number of state-of-the-art OSCs have crossed the threshold of $18 \%$ efficiency, setting up a bright future for anticipated entry market applications [2,5]. However, the synthesis of semiconducting polymers has been plagued by issues such as batchto-batch reproducibility, difficulty in purification, and high polydispersity in molecular weight $[6,7]$. There has been a growing enthusiasm for the use of small-molecule donors as an alternative class of active donors because small-molecule materials have the natural 
benefits of well-defined chemical structures, easy purification, and excellent batch-tobatch reproducibility [6,7]. One concern is that the PCEs of current all-small-molecule (ASM) OSCs lag behind those of polymer-based OSCs. Therefore, the advancement of the photovoltaic performance of ASM OSCs is essential.

There are three main factors causing the lag of ASM OSCs behind polymer-based PCEs. First, there is currently a lack of high-performance small-molecule donors. Only ten kinds of highly efficient small-molecule donors constructed of binary and/or ternary ASM OSCs with PCEs exceeding 13\% have been reported (Table S1 in the Supplementary Material) [8-18]; these are extremely rare in comparison with the more prevalent highly efficient polymer donors and small-molecule NFAs. Therefore, continuing efforts to develop small-molecule donors are essential to promoting the efficiency of ASM OSCs. Another major factor is morphology, which is a well-known difficulty regarding ASM OSCs. The morphology of the active layer is closely related to the manufacturing technique and treatment process, but is also influenced by the natural abilities of the materials, such as molecular crystallinity, intermolecular packing, and the miscibility of the small-molecule mixture [11,12]. Usually, both small-molecule donors and NFAs have a similar acceptordonor-acceptor (A-D-A) molecular skeleton, and many suffer from a difficulty in forming pre-aggregation in solution, as with most polymer materials, thus making it difficult to form an ideal blended-film morphology [15]. Furthermore, it is difficult to find appropriate relative crystallinity for donors/acceptors in pairs within an active layer mixture, even though the well-matched crystallinity of small-molecule donors/acceptors is important for prominent phase separation and film morphology. Because NFAs with planar and $\pi$-conjugated fused-ring structures often lead to low solubility, other small-molecule materials with good solubility are needed in order to regulate the intermolecular interaction and prevent excessive aggregation during the film formation process [19-22]. In other words, solubility is a necessary regulatory factor when designing new small-molecule donors.

To address these issues, we chose two long-chain alkyl cyanoacetate as the endcapped electron-withdrawing moieties for new small-molecule donors because of their natural solubility and flexibility, provided by their alkyl chains and ester bonds [22]. After adding them to a chlorinated two-dimensional benzo[1,2-b:4,5- $\left.\mathrm{b}^{\prime}\right]$ dithiophene (BDT) central electron-donating unit through conjugated alkyl thiophene bridging ligands, two isomeric small-molecule donors were synthesized, namely BT- $\mathrm{R}_{\mathrm{O}}-\mathrm{Cl}$ and $\mathrm{BT}-\mathrm{R}_{\mathrm{EH}}-\mathrm{Cl}$; these have the same A-D-A type structure, except for the different configuration of terminal alkyl chains, each bearing linear n-octyl $(\mathrm{O})$ and another branched 2-ethylhexyl (EH). BT- $\mathrm{R}_{\mathrm{O}}-\mathrm{Cl}$ and BT$\mathrm{R}_{\mathrm{EH}}-\mathrm{Cl}$ exhibit extremely similar molecular energy levels, absorption, and thermal stability, despite a significant difference in solubility and molecular stacking orientation. When applied to ASM OSCs with small-molecule NFA Y6, BT- $\mathrm{R}_{\mathrm{EH}}-\mathrm{Cl}$ displayed uniform phaseseparation morphology and an appropriate combination of face-on and edge-on molecular stacking for donors/acceptors, which formed a more fluent 3D transport channel and thus delivered higher and more balanced carrier mobilities and gained superior photovoltaic performance approaching $14 \%$ efficiency.

\section{Materials and Methods}

\subsection{Materials Synthesis and Characterization}

The two molecular structures for small-molecule donors in this article are shown in Figure 1. They are abbreviated as BT- $\mathrm{R}_{\mathrm{O}}-\mathrm{Cl}$ and $\mathrm{BT}-\mathrm{R}_{\mathrm{EH}}-\mathrm{Cl}$, respectively. Both were obtained conveniently using Stille coupling and the Knoevenagel condensation reaction. Precursor 1 was obtained by the same method as in our previous work [9]. The Knoevenagel condensation reaction was performed between precursor 1 and the purchased terminal compounds. The detailed synthetic processes of the two molecules are shown in Figure 1. The structural characterization of the target molecule is described below and in the Supporting Information (Figures S1-S6). 


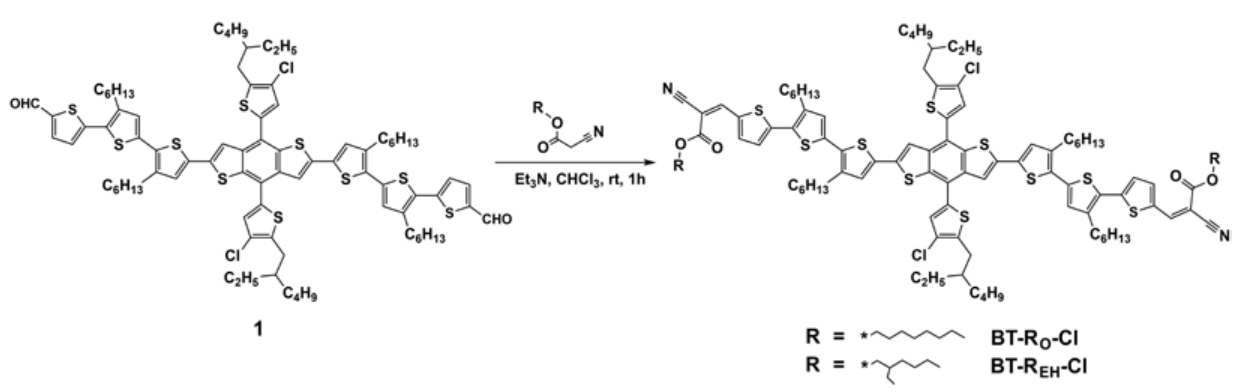

Figure 1. The synthetic route of $\mathrm{BT}-\mathrm{R}_{\mathrm{O}}-\mathrm{Cl}$ and $\mathrm{BT}-\mathrm{R}_{\mathrm{EH}}-\mathrm{Cl}$.

Synthesis of BT- $\mathrm{R}_{\mathrm{O}}-\mathrm{Cl}$ : Compound 1 (0.1442 g, $\left.0.0940 \mathrm{mmol}\right)$ dissolved in dry chloroform $(10 \mathrm{~mL})$ was stirred in a protective atmosphere of $\mathrm{N}_{2}$, and octyl cyanoacetate $(0.3710 \mathrm{~g}$, $1.881 \mathrm{mmol})$ was added. Then, $\mathrm{Et}_{3} \mathrm{~N}(1.5 \mathrm{~mL})$ was added to the above solution. The mixture was stirred for one hour uninterrupted at room temperature, then poured into $\mathrm{CH}_{3} \mathrm{OH}$ (200 mL). After filtration and precipitation, the crude product was obtained. The crude product was then subjected to silica gel column chromatography for purification using the eluting agent of chloroform/petroleum ether $(v / v=3: 1)$. A dark-purple solid $(0.1474 \mathrm{mg}$, $83.3 \%$ ) was obtained as the final pure product after abstersion with $\mathrm{CH}_{3} \mathrm{OH}$, petroleum ether (PE) and propanone (PA). ${ }^{1} \mathrm{H}$ NMR $\left(400 \mathrm{MHz}, \mathrm{CDCl}_{3}\right) \delta 8.26(\mathrm{~s}, 2 \mathrm{H}), 7.77(\mathrm{~d}, 2 \mathrm{H})$, $7.56(\mathrm{~s}, 2 \mathrm{H}), 7.26(\mathrm{~s}, 2 \mathrm{H}), 7.25(\mathrm{~d}, 2 \mathrm{H}), 7.14(\mathrm{~s}, 2 \mathrm{H}), 7.03(\mathrm{~s}, 2 \mathrm{H}), 4.29(\mathrm{t}, 4 \mathrm{H}), 2.94-2.87(\mathrm{~m}, 4 \mathrm{H})$, $2.84(\mathrm{t}, 4 \mathrm{H}), 2.78(\mathrm{t}, 4 \mathrm{H}), 1.81-1.66(\mathrm{~m}, 14 \mathrm{H}), 1.53-1.29(\mathrm{~m}, 60 \mathrm{H}), 1.00(\mathrm{t}, 6 \mathrm{H}), 0.95(\mathrm{t}, 6 \mathrm{H})$, 0.93-0.87 (m, 18H). ${ }^{13} \mathrm{C}$ NMR $\left(151 \mathrm{MHz}, \mathrm{CDCl}_{3}\right) \delta 190.13,163.08,146.24,145.74,142.94$, $139.90,138.78,138.04,137.76,137.33,136.26,135.49,134.87,130.80,129.58,129.28,128.06$, 126.17, 122.91, 122.48, 118.56, 116.01, 101.04, 97.81, 77.21, 77.00, 76.79, 66.55, 40.91, 38.92, $33.35,33.28,32.59,32.26,31.77,31.64,30.32,30.23,30.15,29.99,29.70,29.26,29.22,29.18$, $29.14,28.87,28.58,26.76,26.00,25.81,23.05,22.63,22.59,14.17,14.05,10.94$. ESI-Q-TOF-MS $m / z$ calcd. for $\mathrm{C}_{106} \mathrm{H}_{137} \mathrm{Cl}_{2} \mathrm{~N}_{2} \mathrm{O}_{4} \mathrm{~S}_{10}: 631.56[\mathrm{M}+3 \mathrm{H}]^{3+}$; found: 630.57 .

Synthesis of BT- $\mathrm{R}_{\mathrm{EH}}-\mathrm{Cl}$ : BT- $\mathrm{R}_{\mathrm{EH}}-\mathrm{Cl}$ was obtained by a similar synthetic route of BT$\mathrm{R}_{\mathrm{O}}-\mathrm{Cl}$, except for the use of 2-ethylhexyl cyanoacetate instead of octyl cyanoacetate, and a higher yield of $92.9 \%$ for the target product (dark-purple solid). ${ }^{1} \mathrm{H}$ NMR $(400 \mathrm{MHz}$, $\left.\mathrm{CDCl}_{3}\right) \delta 8.25(\mathrm{~s}, 2 \mathrm{H}), 7.77(\mathrm{~d}, 2 \mathrm{H}), 7.56(\mathrm{~s}, 2 \mathrm{H}), 7.25(\mathrm{~s}, 2 \mathrm{H}), 7.24(\mathrm{~d}, 2 \mathrm{H}), 7.13(\mathrm{~s}, 2 \mathrm{H})$, $7.03(\mathrm{~s}, 2 \mathrm{H}), 4.25-4.18(\mathrm{~m}, 4 \mathrm{H}), 2.94-2.87(\mathrm{~m}, 4 \mathrm{H}), 2.84(\mathrm{t}, 4 \mathrm{H}), 2.78(\mathrm{t}, 4 \mathrm{H}), 1.82-1.77(\mathrm{~m}, 2 \mathrm{H})$, $1.75-1.66(\mathrm{~m}, 10 \mathrm{H}), 1.52-1.32(\mathrm{~m}, 56 \mathrm{H}), 1.00(\mathrm{t}, 6 \mathrm{H}), 0.96-0.88(\mathrm{~m}, 30 \mathrm{H}) .{ }^{13} \mathrm{C} \mathrm{NMR}(101 \mathrm{MHz}$, $\left.\mathrm{CDCl}_{3}\right) \delta 190.63,163.22,146.26,145.77,142.96,141.34,138.73,138.64,138.03,137.90,137.31$, 136.24, 135.47, 135.19, 134.85, 130.78, 129.58, 129.29, 128.72, 128.04, 126.16, 122.89, 122.45, 118.56, 115.98, 104.12, 97.72, 77.34, 77.02, 76.70, 68.79, 40.88, 38.80, 32.53, 32.22, 31.66, 30.33, $30.23,29.99,29.71,29.29,29.24,28.93,28.85,25.95,23.77,23.07,22.96,22.62,22.60,14.22$, $14.11,14.10,14.06,11.03,10.95$. ESI-Q-TOF-MS $m / z$ calcd. for $\mathrm{C}_{106} \mathrm{H}_{137} \mathrm{Cl}_{2} \mathrm{~N}_{2} \mathrm{O}_{4} \mathrm{~S}_{10}: 631.56$ $[\mathrm{M}+3 \mathrm{H}]^{3+}$; found: 630.23 .

\subsection{Device Fabrication and Testing}

The device structures were composed of indium tin oxide (ITO)/poly(3,4-ethylenedioxythio-phene):poly(styrene sulfonate) (PEDOT:PSS)/active layer (donor: Y6)/phenyl (2-naphthyl) diphenylphosphine oxide (Phen-NaDPO)/Ag. The PEDOT:PSS was used as a hole transport layer (HTL), and Phen-NaDPO was taken for an electron transport layer (ETL). The detailed fabrication process and testing methods for devices are illustrated in the corresponding sections of the Supporting Information. The key parameters for the device optimization are summarized in Tables S2-S10, including manipulation of the weight ratios of the donor/acceptor, thickness of the active layer, temperature of thermal annealing (TA), and time of solvent vapor annealing (SVA). 


\section{Results and Discussion}

\subsection{Materials Structure and Properties}

BT- $\mathrm{R}_{\mathrm{O}}-\mathrm{Cl}$ and BT- $\mathrm{R}_{\mathrm{EH}}-\mathrm{Cl}$ are isomeric small-molecules, where $\mathrm{BT}-\mathrm{R}_{\mathrm{O}}-\mathrm{Cl}$ adopts octyl cyanoacetate with a linear alkyl chain as the terminal unit and BT- $\mathrm{E}_{\mathrm{EH}}-\mathrm{Cl}$ adopts 2-ethylhexyl cyanoacetate with a branched alkyl chain as the terminal moiety (Figure 2a). As expected, BT- $\mathrm{R}_{\mathrm{O}}-\mathrm{Cl}$ and $\mathrm{BT}-\mathrm{R}_{\mathrm{EH}}-\mathrm{Cl}$ showed nearly identical molecular energy levels and solution and film absorption (Figure 2c,d). The highest occupied molecular orbital (HOMO) energy levels and the lowest unoccupied molecular orbital (LUMO) energy levels were evaluated by cyclic voltammetry. The HOMO levels of BT- $\mathrm{R}_{\mathrm{O}}-\mathrm{Cl}$ and $\mathrm{BT}-\mathrm{R}_{\mathrm{EH}}-\mathrm{Cl}$ films were the same, with a value of $-5.41 \mathrm{eV}$, while the LUMO levels showed a slight difference $(-3.57 \mathrm{eV}$ for $\mathrm{BT}-\mathrm{R}_{\mathrm{O}}-\mathrm{Cl}$ and $-3.58 \mathrm{eV}$ for $\mathrm{BT}-\mathrm{R}_{\mathrm{EH}}-\mathrm{Cl}$ ) (Figures $2 \mathrm{c}$ and $\mathrm{S7}$ ). The solution absorption spectra of BT- $\mathrm{R}_{\mathrm{O}}-\mathrm{Cl}$ and $\mathrm{BT}-\mathrm{R}_{\mathrm{EH}}-\mathrm{Cl}$ were also similar, and the maximum absorption peaks were both located at $504 \mathrm{~nm}$ with slight differences between absorption coefficients $\left(1.00 \times 10^{5} \mathrm{Mol}^{-1} \mathrm{~cm}^{-1}\right.$ for BT-R $\mathrm{O}_{-} \mathrm{Cl}$ and $1.01 \times 10^{5} \mathrm{Mol}^{-1} \mathrm{~cm}^{-1}$ for BT- $\left.\mathrm{R}_{\mathrm{EH}}-\mathrm{Cl}, \lambda=504 \mathrm{~nm}\right)$ (Figures $2 \mathrm{~d}$ and S8). In solid films, both BT- $\mathrm{R}_{\mathrm{O}}-\mathrm{Cl}$ and BT- $\mathrm{R}_{\mathrm{EH}}-\mathrm{Cl}$ showed additional shoulder peaks, owing to the strong intermolecular interactions for free accumulation [23]. The maximum peaks of the $\mathrm{BT}-\mathrm{R}_{\mathrm{O}}-\mathrm{Cl}$ film were located at 560 and $604 \mathrm{~nm}$, and the red-shift was $56 \mathrm{~nm}$ compared with solution absorption. For the BT- $\mathrm{R}_{\mathrm{EH}}-\mathrm{Cl}$ film, the maximum peaks were located at 564 and $610 \mathrm{~nm}$ and the red-shift was $60 \mathrm{~nm}$. BT- $\mathrm{R}_{\mathrm{EH}}-\mathrm{Cl}$ had a slightly greater red-shift and a higher absorption coefficient compared with BT- $\mathrm{R}_{\mathrm{O}}-\mathrm{Cl}$, implying slightly stronger intermolecular interactions and crystallinity in BT- $\mathrm{R}_{\mathrm{EH}}-\mathrm{Cl}$ solid films [23]. On the basis of film absorption, the optical gaps $\left(\mathrm{E}_{\mathrm{g}}{ }^{\mathrm{opt}} \mathrm{s}\right)$ of $\mathrm{BT}-\mathrm{R}_{\mathrm{O}}-\mathrm{Cl}(1.84 \mathrm{eV})$ and $\mathrm{BT}-\mathrm{R}_{\mathrm{EH}}-\mathrm{Cl}(1.83 \mathrm{eV})$ were calculated, and were in agreement with the measurements by cyclic voltammetry (Table 1 ). Table 1 shows the rounded parameters of the optical and electrochemical properties for $\mathrm{BT}-\mathrm{R}_{\mathrm{O}}-\mathrm{Cl}$ and $\mathrm{BT}-\mathrm{R}_{\mathrm{EH}}-\mathrm{Cl}$.

(a)

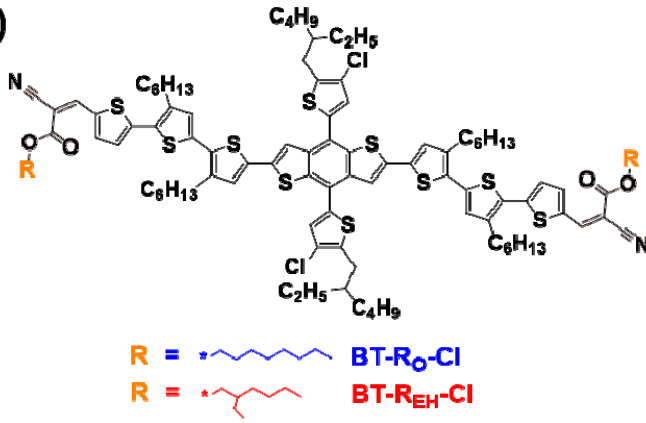

(c)

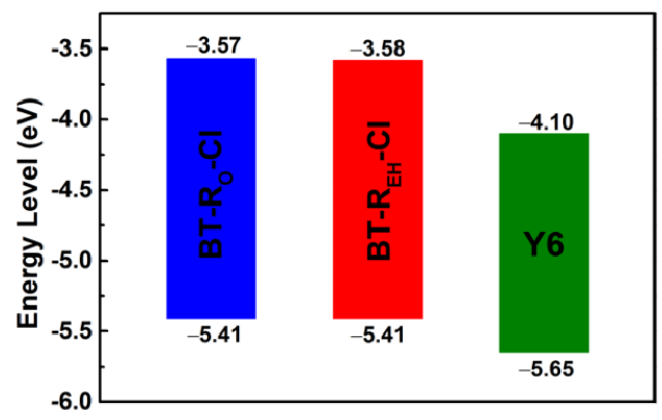

(b)

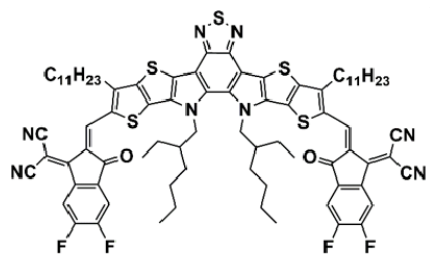

Y6

(d)

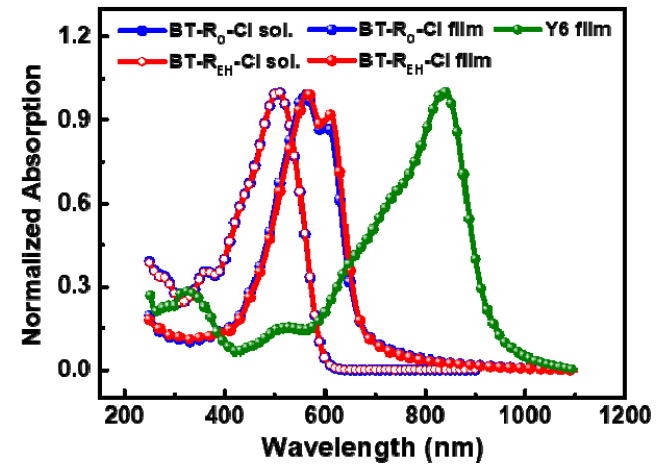

Figure 2. (a,b) The molecular structure; (c) energy level; and (d) solution (in chloroform) and film absorption of BT- $\mathrm{R}_{\mathrm{O}}-\mathrm{Cl}$, BT- $\mathrm{R}_{\mathrm{EH}}-\mathrm{Cl}$, and $\mathrm{Y} 6$. 
Table 1. Parameters of the optical, electrochemical, and solubility nature of $\mathrm{BT}-\mathrm{R}_{\mathrm{O}}-\mathrm{Cl}$ and $\mathrm{BT}-\mathrm{R}_{\mathrm{EH}}-\mathrm{Cl}$.

\begin{tabular}{|c|c|c|c|c|c|c|c|c|}
\hline Materials & $\begin{array}{c}\text { HOMO }^{\mathrm{cv}} \\
(\mathrm{eV})\end{array}$ & $\begin{array}{l}\text { LOMO }^{\mathrm{cv}} \\
(\mathrm{eV})\end{array}$ & $\begin{array}{l}E_{\mathrm{g}} \mathrm{cv} \\
(\mathrm{eV})\end{array}$ & $\begin{array}{c}\lambda_{\max }^{\text {sol }} \\
(\mathrm{nm})\end{array}$ & $\begin{array}{c}\lambda_{\max } \text { film } \\
\text { (nm) }\end{array}$ & $\begin{array}{l}\lambda_{\text {onset }}^{\text {film }} \\
\text { (nm) }\end{array}$ & $\begin{array}{l}\text { (a) } E_{\mathrm{g}} \text { opt } \\
(\mathrm{eV})\end{array}$ & $\begin{array}{l}\text { (b) Sol. } \\
\left(\mathrm{mg} \mathrm{mL}^{-1}\right)\end{array}$ \\
\hline BT-R ${ }-C l$ & -5.41 & -3.57 & 1.84 & 504 & 560,604 & 673 & 1.84 & 76.5 \\
\hline $\mathrm{BT}-\mathrm{R}_{\mathrm{EH}}-\mathrm{Cl}$ & -5.41 & -3.58 & 1.83 & 504 & 564,610 & 676 & 1.83 & 158.1 \\
\hline
\end{tabular}

(a) Calculation: $E_{\mathrm{g}}{ }^{\mathrm{opt}}=1240 / \lambda_{\text {onset }}{ }^{\text {film }}(\mathrm{eV})$; $^{\text {(b) }}$ the solubility in chloroform

By comparison testing the absorption intensity of different known concentration solutions and diluted solutions of saturated solutions, we obtained the solubilities of BT- $\mathrm{R}_{\mathrm{O}}-\mathrm{Cl}$ and BT- $\mathrm{R}_{\mathrm{EH}}-\mathrm{Cl}$ in chloroform. Interestingly, $\mathrm{BT}-\mathrm{R}_{\mathrm{EH}}-\mathrm{Cl}\left(158.1 \mathrm{mg} \mathrm{mL}{ }^{-1}\right)$ was much more soluble in chloroform than $\mathrm{BT}-\mathrm{R}_{\mathrm{O}}-\mathrm{Cl}\left(76.5 \mathrm{mg} \mathrm{mL}^{-1}\right)$, demonstrating the good solubilizing ability and flexibility of branched alkyl chains in contrast to linear alkyl chains as the terminal unit. Additionally, the different solubilities of BT- $\mathrm{R}_{\mathrm{O}}-\mathrm{Cl}$ and $\mathrm{BT}-\mathrm{R}_{\mathrm{EH}}-\mathrm{Cl}$ prefigured their different molecular arrangements and molecular stacking orientations, as recently reported by Jones and our group $[9,24]$. We can see that both BT- $\mathrm{R}_{\mathrm{O}}-\mathrm{Cl}$ and BT- $\mathrm{R}_{\mathrm{EH}}-\mathrm{Cl}$ displayed sound thermal stability with a high decomposition temperature around $375{ }^{\circ} \mathrm{C}$ from their thermogravimetric analysis (TGA) curves (Figure S10a), yet BT- $\mathrm{R}_{\mathrm{O}}-\mathrm{Cl}$ had a higher transition temperature than BT- $\mathrm{R}_{\mathrm{EH}}-\mathrm{Cl}$, as can be seen in their differential scanning calorimetry (DSC) plots (Figure S10b).

\subsection{Photovoltaic Properties}

To investigate the photovoltaic properties of the two materials, especially the impact of different terminal alkyl chains, ASM OSC devices were designed and manufactured together with $\mathrm{Y} 6$ as an electron acceptor. Both adopted a conventional device structure, that is, ITO/PEDOT:PSS/active layer/Phen-NaDPO/Ag (Figure 3a). Here, Y6 was chosen not only because it is one of the state-of-the-art acceptors in the NFAs community, but also because of its well-matched molecule levels and coincidentally complementary absorption (Figure 2c,d). Without any post treatment, both BT- $\mathrm{R}_{\mathrm{O}}-\mathrm{Cl}$ :Y6- and BT- $\mathrm{R}_{\mathrm{EH}}-\mathrm{Cl}$ :Y6-based devices exhibited a high open-circuit voltage $\left(V_{\text {oc }}\right)$ of around $0.90 \mathrm{~V}$, but average PCEs of $6.95 \%$ and $6.30 \%$, respectively (Table S2). The inferior PCEs for as-cast devices was due to their poor short-circuit current density $\left(J_{\mathrm{sc}}\right)$ and fill factor $(\mathrm{FF})$, so we used both TA and SVA post-treatment technology. After device optimization with a TA and/or SVA process, the $J_{\mathrm{sc}}, \mathrm{FF}$, and PCE distinctly improved. Following TA treatment, BT- $\mathrm{R}_{\mathrm{O}}-\mathrm{Cl}$ :Y6-based devices achieved a maximum PCE of $13.35 \%$ with $V_{\mathrm{oc}}$ of $865.1 \mathrm{mV}, J_{\mathrm{sc}}$ of $22.50 \mathrm{~mA} \mathrm{~cm}^{-2}$, and FF of $68.59 \%$; BT- $\mathrm{R}_{\mathrm{EH}}-\mathrm{Cl}$ :Y6-based devices achieved a maximum PCE of $13.90 \%$ with $V_{\mathrm{oc}}$ of $867.6 \mathrm{mV}, J_{\mathrm{sc}}$ of $22.93 \mathrm{~mA} \mathrm{~cm}^{-2}$, and FF of $69.86 \%$ (Tables S2, S5 and S9). Following SVA treatment, the two system devices achieved superior film morphology, both with a higher $\mathrm{FF}$, exceeding $70 \%$, but a relatively inferior $V_{\mathrm{oc}}$, thus achieving $13.29 \%$ and $13.46 \%$ optimum efficiency for BT- $\mathrm{R}_{\mathrm{O}}-\mathrm{Cl}$ :Y6-based and BT- $\mathrm{R}_{\mathrm{EH}}-\mathrm{Cl}$ :Y6-based devices, respectively (Tables $\mathrm{S} 6$ and $\mathrm{S10}$ ). Figure $3 \mathrm{~b}$ displays the $J-V$ curves of the optimized devices based on BT- $\mathrm{R}_{\mathrm{O}}-\mathrm{Cl}: Y 6$ and BT- $\mathrm{R}_{\mathrm{EH}}-\mathrm{Cl}: \mathrm{Y} 6$ films. Table 2 displays the optimized device parameters corresponding to Figure 3b. Figure $3 \mathrm{c}$ shows the histograms and corresponding Gaussian distributions of PCE counts (40 individual devices) for the TA treatment of ASM OSC devices, indicating good reproducibility of the BT- $\mathrm{R}_{\mathrm{O}}-\mathrm{Cl}: \mathrm{Y} 6-$ and BT- $\mathrm{R}_{\mathrm{EH}}-\mathrm{Cl}: \mathrm{Y} 6-$ based devices. Moreover, the near- $14 \%$ optimum efficiency enriched the highly efficient ASM OSCs, indicating BT- $\mathrm{R}_{\mathrm{EH}}-\mathrm{Cl}$ 's promise as a new member of the community of highly efficient small-molecule donors. In comparison with our reported small-molecule donor BTR-Cl [9], which has the same center core but rhodamine as the terminal group, BT- $\mathrm{R}_{\mathrm{EH}}-\mathrm{Cl}$ was obtained by a more simplified synthetic process and higher synthetic productivity (over 90\% yield), and has a conveniently purchased terminal compound, portending a wider and readier commercialization for the material market. 
(a)

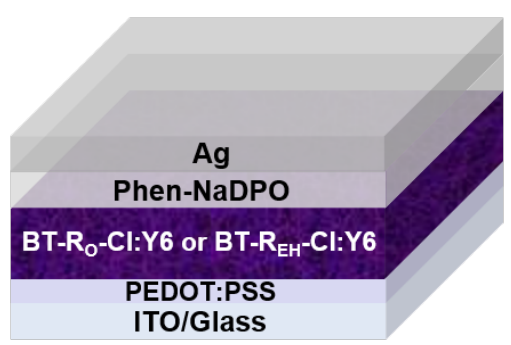

(c)

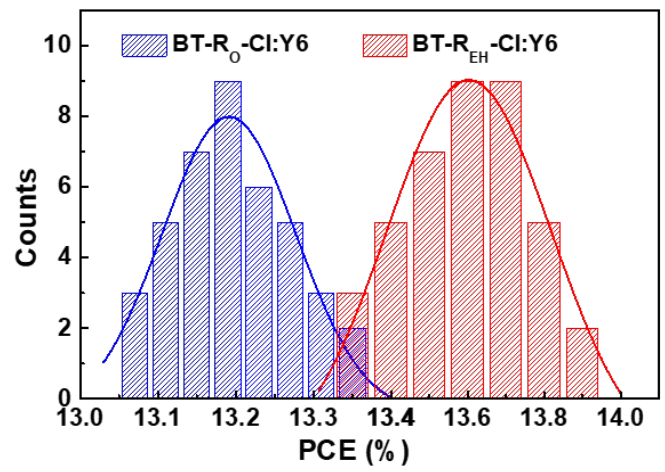

(b)

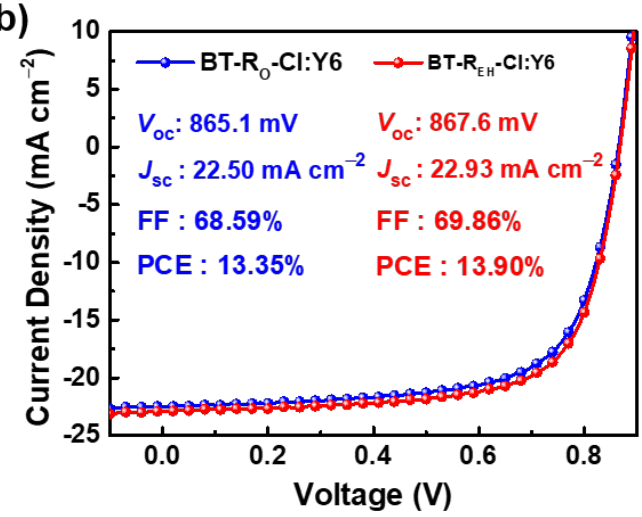

(d)

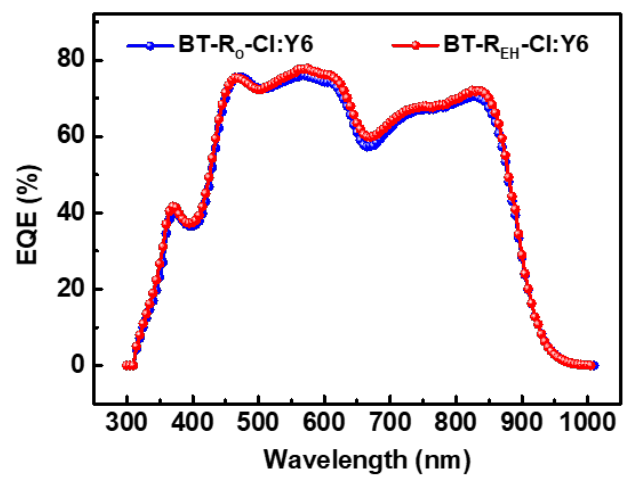

Figure 3. (a) The device structure; (b) $J-V$ curves of the optimal devices; (c) statistical diagram of PCE counts for 40 individual devices; and (d) EQE curves of the optimal devices.

Regarding the EQE curves of the optimized devices (Figure 3d), the photoresponse region and tendency were very similar, but a slight difference was observed in the response intensity. In the range of $550 \mathrm{~nm}$ to $850 \mathrm{~nm}$ for the EQE testing wavelength, the response intensity of BT- $\mathrm{R}_{\mathrm{EH}}-\mathrm{Cl}$ :Y6-based devices was much higher than that of BT- $\mathrm{R}_{\mathrm{O}}-\mathrm{Cl}$ :Y6-based devices. The three maximum EQE peak values of BT- $\mathrm{R}_{\mathrm{EH}}-\mathrm{Cl}$ :Y6-based devices were $75.3 \%$ at $465 \mathrm{~nm}, 77.9 \%$ at $575 \mathrm{~nm}$, and $72.0 \%$ at $835 \mathrm{~nm}$, while the three maximum EQE values of BT-Ro-Cl:Y6-based devices were $75.6 \%$ at $475 \mathrm{~nm}, 76.0 \%$ at $565 \mathrm{~nm}$, and $70.6 \%$ at $825 \mathrm{~nm}$. This reveals not only the much higher response intensity of BT- $\mathrm{R}_{\mathrm{EH}}-\mathrm{Cl}$ :Y6-based devices, but also a slight red-shifted $(10 \mathrm{~nm})$ response in the wavelength range from $550 \mathrm{~nm}$ to $850 \mathrm{~nm}$. To determine the reason for the EQE enhancement, we evaluated the photo absorption of BT- $\mathrm{R}_{\mathrm{O}}-\mathrm{Cl}: \mathrm{Y} 6$ and BT- $\mathrm{R}_{\mathrm{EH}}-\mathrm{Cl}: \mathrm{Y} 6$ blended films, which were prepared under optimal device conditions on PEDOT:PSS-coated ITO (Figure S11, no normalization). We obtained a slightly stronger photo absorption of BT- $\mathrm{R}_{\mathrm{EH}}-\mathrm{Cl}: \mathrm{Y} 6$ blended films compared with BT$\mathrm{R}_{\mathrm{O}}-\mathrm{Cl}: \mathrm{Y} 6$ blended films, which is in reasonable agreement with the EQE transformation and correspondingly fitted to the higher $J_{\mathrm{sc}}$ of BT- $\mathrm{R}_{\mathrm{EH}}-\mathrm{Cl}$ :Y6-based devices compared with BT- $\mathrm{R}_{\mathrm{O}}-\mathrm{Cl}$ :Y6-based devices. By fitting calculation, the $J_{\mathrm{EQE}}$ of the BT- $\mathrm{R}_{\mathrm{O}}-\mathrm{Cl}: \mathrm{Y} 6-$ based device was $22.16 \mathrm{~mA} \mathrm{~cm}^{-2}$, and the $J_{\mathrm{EQE}}$ of the BT- $\mathrm{R}_{\mathrm{EH}}-\mathrm{Cl}: Y 6$-based device was $22.63 \mathrm{~mA} \mathrm{~cm}^{-2}$ (Table 2); both were well-matched with their $J_{\mathrm{sc}}$ values, with a less than $2 \%$ mismatch. On the other hand, the increased $J_{\mathrm{sc}}$ of BT- $\mathrm{R}_{\mathrm{EH}}-\mathrm{Cl}$ :Y6-based devices was also in line with the improved charge mobilities and recombination as well as the superior morphology, which will be discussed below. 
Table 2. Photovoltaic parameters for the best BT- $\mathrm{R}_{\mathrm{O}}-\mathrm{Cl}: \mathrm{Y} 6$ and BT- $\mathrm{R}_{\mathrm{EH}}-\mathrm{Cl}: \mathrm{Y} 6$ devices.

\begin{tabular}{|c|c|c|c|c|c|c|}
\hline Active Layer & $\begin{array}{c}V_{o c} \\
(\mathrm{mV})\end{array}$ & $\begin{array}{c}J_{\mathrm{sc}} \\
\left(\mathrm{mA} \mathrm{cm}^{-2}\right)\end{array}$ & $\begin{array}{l}\text { FF } \\
(\%)\end{array}$ & $\begin{array}{c}\text { PCE } \\
(\%)\end{array}$ & $\begin{array}{c}\text { (a) } \mathrm{PCE}_{\text {Ave. }} \\
(\%)\end{array}$ & $\begin{array}{c}\text { (b) } J_{\mathrm{sc}} \\
\left(\mathrm{mA} \mathrm{cm}^{-2}\right)\end{array}$ \\
\hline BT-R ${ }_{\mathrm{O}}-\mathrm{Cl}: \mathrm{Y}$ & 865.1 & 22.50 & 68.59 & 13.35 & $13.20 \pm 0.10$ & 22.16 \\
\hline BT- $\mathrm{R}_{\mathrm{EH}}-\mathrm{Cl}: \mathrm{Y} 6$ & 867.6 & 22.93 & 69.86 & 13.90 & $13.52 \pm 0.10$ & 22.63 \\
\hline
\end{tabular}

(a) The $\mathrm{PCE}_{\mathrm{Ave}}$. values were gained by 15 individual devices; ${ }^{(\mathrm{b})}$ the $J_{\mathrm{sc}}$ values were integrated from EQE.

\subsection{Charge Carrier Mobilities and Recombination Dynamics}

A space-charge-limited current (SCLC) model was chosen to obtain dark current densities. These had the following architectures: ITO/PEDOT:PSS/active layer (BT- $\mathrm{R}_{\mathrm{O}^{-}}$ Cl:Y6 or BT- $\mathrm{R}_{\mathrm{EH}}-\mathrm{Cl}: \mathrm{Y} 6$ blended films)/ $\mathrm{MoO}_{3} / \mathrm{Ag}$ and ITO/ZnO/Phen-NaDPO/active layer (BT- $\mathrm{R}_{\mathrm{O}}-\mathrm{Cl}: \mathrm{Y} 6$ or BT- $\mathrm{R}_{\mathrm{EH}}-\mathrm{Cl}: \mathrm{Y} 6$ blended films)/Phen-NaDPO/Ag for the electrononly and hole-only devices. Figure $4 \mathrm{a}-\mathrm{d}$ present the electron and hole mobilities for $\mathrm{BT}-\mathrm{R}_{\mathrm{O}}-\mathrm{Cl}: \mathrm{Y} 6$ or BT- $\mathrm{R}_{\mathrm{EH}}-\mathrm{Cl}: \mathrm{Y} 6$ blended films, respectively. Meanwhile, a clearer contrast of values for hole mobility and electron mobility are shown in Table S11. The BT- $\mathrm{R}_{\mathrm{O}^{-}}$ Cl:Y6 blended film showed finely balanced electron/hole mobilities $\left(\mu_{\mathrm{e}} / \mu_{\mathrm{h}}=1.11\right)$ with values of $2.72 \times 10^{-4} \mathrm{~cm}^{2} \mathrm{~V}^{-1} \mathrm{~s}^{-1}$ and $2.46 \times 10^{-4} \mathrm{~cm}^{2} \mathrm{~V}^{-1} \mathrm{~s}^{-1}$, respectively. The BT- $\mathrm{R}_{\mathrm{EH}^{-}}$ $\mathrm{Cl}: Y 6$ blended film, on the other hand, presented higher values of both electron mobility $\left(3.01 \times 10^{-4} \mathrm{~cm}^{2} \mathrm{~V}^{-1} \mathrm{~s}^{-1}\right)$ and hole mobility $\left(2.81 \times 10^{-4} \mathrm{~cm}^{2} \mathrm{~V}^{-1} \mathrm{~s}^{-1}\right)$. The higher and more balanced electron/hole mobilities in BT- $\mathrm{R}_{\mathrm{EH}}-\mathrm{Cl}$ :Y6-based devices $\left(\mu_{\mathrm{e}} / \mu_{\mathrm{h}}=1.07\right)$ drove higher $J_{\mathrm{sc}}$ and $\mathrm{FF}$ values for the corresponding devices [25].

(a)

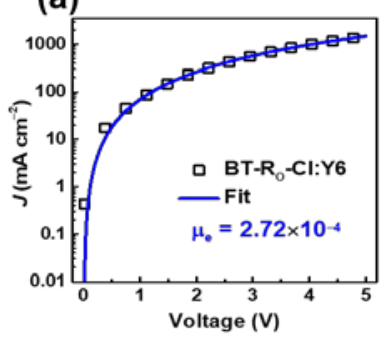

(e)

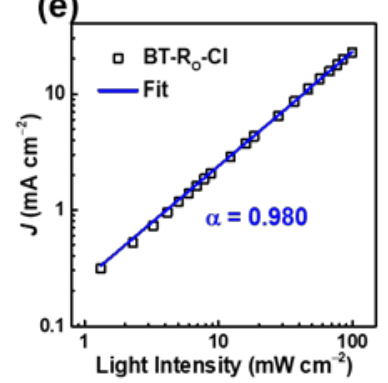

(b)

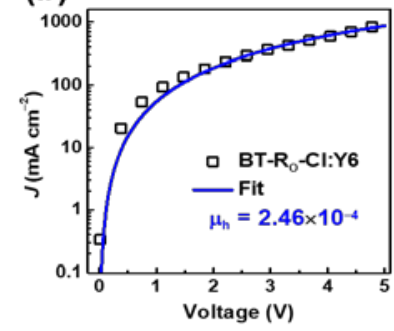

(f)

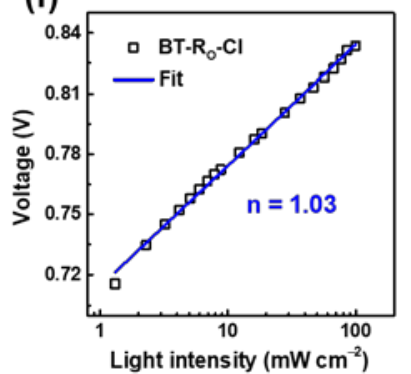

(c)

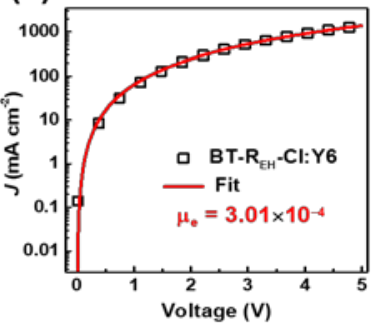

(g)

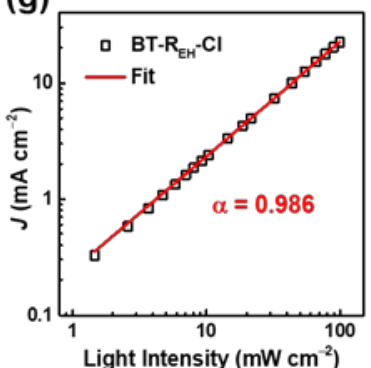

(d)

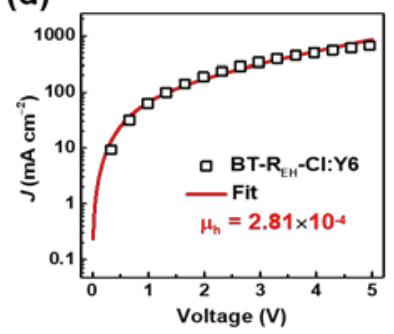

(h)

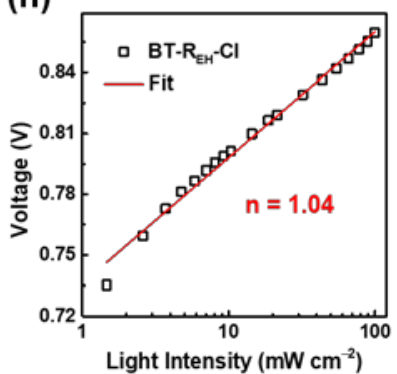

Figure 4. (a-d) $J-V$ characteristics in the dark for electron and hole mobility measurement for BT- $\mathrm{R}_{\mathrm{O}}-\mathrm{Cl}: \mathrm{Y} 6$ and BT- $\mathrm{R}_{\mathrm{EH}}{ }^{-}$ $\mathrm{Cl}: Y 6$ blended films. (e-h) The fitted results of $J_{\mathrm{sc}}$ and $V_{\mathrm{oc}}$ under various incident light intensities. Fitted equations: $J_{\mathrm{sc}} \propto I^{\alpha}$ and $V_{\mathrm{oc}} \propto n(k T / q) \ln (I)$.

The charge carrier recombination patterns of these devices were also examined. This was performed by measuring the $J-V$ characteristics under various incident light intensities (Figure S12). Previous research work reported that the $J_{\mathrm{sc}}$ and the incident light intensity I followed a power-law: $J_{\mathrm{sc}} \propto I^{\alpha} . \alpha$ values reflect bimolecular recombination effects; if the power factor $\alpha=1$, free charge extraction is unaffected by bimolecular recombination [26]. From Figure 4e,g, $\alpha$ values of 0.980 and 0.986 were fitted for BT- $\mathrm{R}_{\mathrm{O}}-\mathrm{Cl}: \mathrm{Y} 6$ and BT- $\mathrm{R}_{\mathrm{EH}}-\mathrm{Cl}: \mathrm{Y} 6$ devices, respectively, indicating that both BT- $\mathrm{R}_{\mathrm{O}}-\mathrm{Cl}: \mathrm{Y} 6$ and BT- $\mathrm{R}_{\mathrm{EH}}-\mathrm{Cl}: \mathrm{Y} 6$ devices fortunately possessed weak bimolecular recombination. At the same time, the $V_{\text {oc }}$ 
under various incident light intensities $(I)$ was measured and plotted for the estimation of trap-assisted recombination. This was fitted by $V_{\mathrm{oc}} \propto n(k T / q) \ln (I)$, where $k, T$, and $q$ are respectively the Boltzmann constant, temperature in kelvin, and the elementary charge. If the value of $n$ deviates far from 1 , it indicates that the device suffers badly from trapinduced recombination [26]. Figure 4f,h displays the fitted data. The $n$ values of 1.03 and 1.04 for BT- $\mathrm{R}_{\mathrm{O}}-\mathrm{Cl}: \mathrm{Y} 6$ and $\mathrm{BT}-\mathrm{R}_{\mathrm{EH}}-\mathrm{Cl}: \mathrm{Y} 6$ devices indicate that both the BT- $\mathrm{R}_{\mathrm{O}}-\mathrm{Cl}: \mathrm{Y} 6$ and the BT- $\mathrm{R}_{\mathrm{EH}}-\mathrm{Cl}: \mathrm{Y} 6$ devices were not troubled by trap-assisted recombination, which corresponds to their balanced hole and electron transport.

\subsection{Morphology and Microstructure Characterization}

Another disparity between the electronic parameters of the BT- $\mathrm{R}_{\mathrm{EH}}-\mathrm{Cl}: \mathrm{Y} 6$ device and the BT- $\mathrm{R}_{\mathrm{O}}-\mathrm{Cl}: \mathrm{Y} 6$ device is the FF. To gain insight into the photovoltaic difference between BT- $\mathrm{R}_{\mathrm{O}}-\mathrm{Cl}$ and $\mathrm{BT}-\mathrm{R}_{\mathrm{EH}}-\mathrm{Cl}$, we studied the morphology in detail for pure and/or blended films via atomic force microscopy (AFM) and transmission electron microscopy (TEM). Both BT- $\mathrm{R}_{\mathrm{EH}^{-}} \mathrm{Cl}: \mathrm{Y} 6$ with BT- $\mathrm{R}_{\mathrm{O}}-\mathrm{Cl}: \mathrm{Y} 6$ films had smooth surfaces. A slight difference in surface root-mean-square (RMS) roughness was found, where BT- $\mathrm{R}_{\mathrm{EH}}-\mathrm{Cl}: \mathrm{Y} 6$ films had RMS values of $2.7 \mathrm{~nm}$, while BT- $\mathrm{R}_{\mathrm{O}}-\mathrm{Cl}$ :Y6 films had RMS values of $2.4 \mathrm{~nm}$ (Figure 5a,b). Not only a slightly higher RMS for BT- $\mathrm{R}_{\mathrm{EH}}-\mathrm{Cl}$ :Y6 films, but also a somewhat smoother and more uniform surface was obtained by AFM phase images (Figure 5c,d) and TEM patterns (Figure 5e-f). There was no huge distinction between surface morphology in the two blended systems, corresponding to the tiny structural differences between the two isomeric molecular and different crystallinities of mixture [27].

(a)

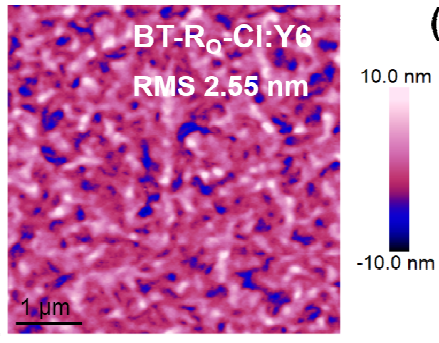

(c)

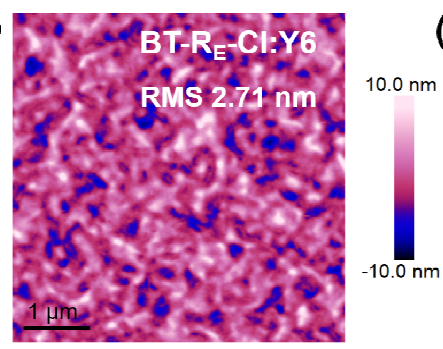

(b)

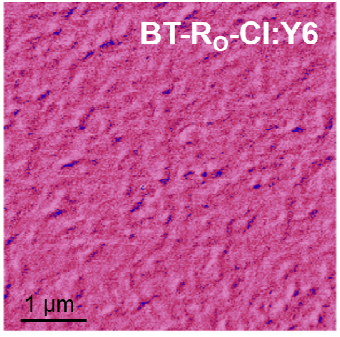

(d)

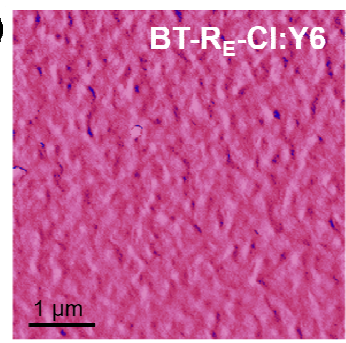

(e)

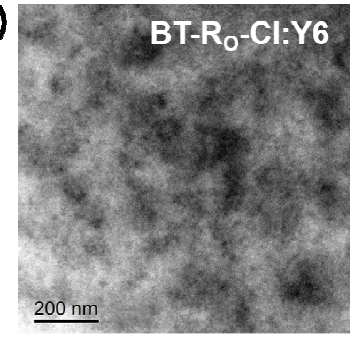

(f)

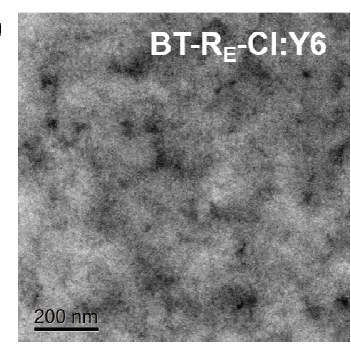

Figure 5. The surface morphology of BT- $\mathrm{R}_{\mathrm{O}}-\mathrm{Cl}: \mathrm{Y} 6$ and $\mathrm{BT}-\mathrm{R}_{\mathrm{EH}}-\mathrm{Cl}: \mathrm{Y} 6$ blended films: (a-d) AFM and $(\mathbf{e}, \mathbf{f})$ TEM images.

Grazing incidence wide-angle X-ray scattering (GIWAXS) was carried out to gain insight into molecular packing, stacking orientation, and crystallinity in the two systems. The pure and blended films of the small-molecule donors and acceptors were studied. From Figure 6a,e, we see that the pure BT- $\mathrm{R}_{\mathrm{O}}-\mathrm{Cl}$ film displayed lamellar stacking with isotropic ( $h 00)$ diffraction peaks in both out-of-plane (corresponding to $q_{z}$ profiles) and in-plane (corresponding to $q_{x y}$ profiles) directions. The $\pi-\pi$ stacking with a (010) diffraction peak appeared clearly in the in-plane direction. The pure BT- $\mathrm{R}_{\mathrm{EH}}-\mathrm{Cl}$ film exhibited a moreordered molecular packing and orientation, whereas the lamellar stacking with isotropic (h00) diffraction peaks only existed in out-of-plane directions, with a nearly identical appearance of $\pi-\pi$ stacking in the $q_{x y}$ direction. Moreover, estimated by the Scherrer equation [28], the two pure films revealed similar $\pi-\pi$ stacking $d$-spacing but a shorter 
lamellar stacking $\mathrm{d}$-spacing for the BT- $\mathrm{R}_{\mathrm{EH}}-\mathrm{Cl}$ pure film (Figure S13). The same appearance of $\pi-\pi$ stacking for pure films was due to their uniform conjugated molecular backbone [29]. The differences in order and in lamellar stacking d-spacing can be attributed to their nonuniform types of aggregation, and correspond to their different $0-0 / 0-1$ vibronic peak ratio of film absorption maximum peaks [29]. From the patterns of BT- $\mathrm{R}_{\mathrm{O}}-\mathrm{Cl}: Y 6$ and BT- $\mathrm{EH}^{-}$ Cl:Y6 blended films (Figure $6 c-f$ ), we see that (010) $\pi-\pi$ diffraction peaks arose in both in-plane and out-of-plane axes. This demonstrates that both $\mathrm{BT}-\mathrm{R}_{\mathrm{O}}-\mathrm{Cl}$ and $\mathrm{BT}-\mathrm{R}_{\mathrm{EH}}-\mathrm{Cl}$ can form fluent three-dimensional (3D) charge transport channels after linking with Y6. The coexistence of both vertical and parallel transport channels enormously boosted efficient charge transport processes, thus improving the photovoltaic performance [30].
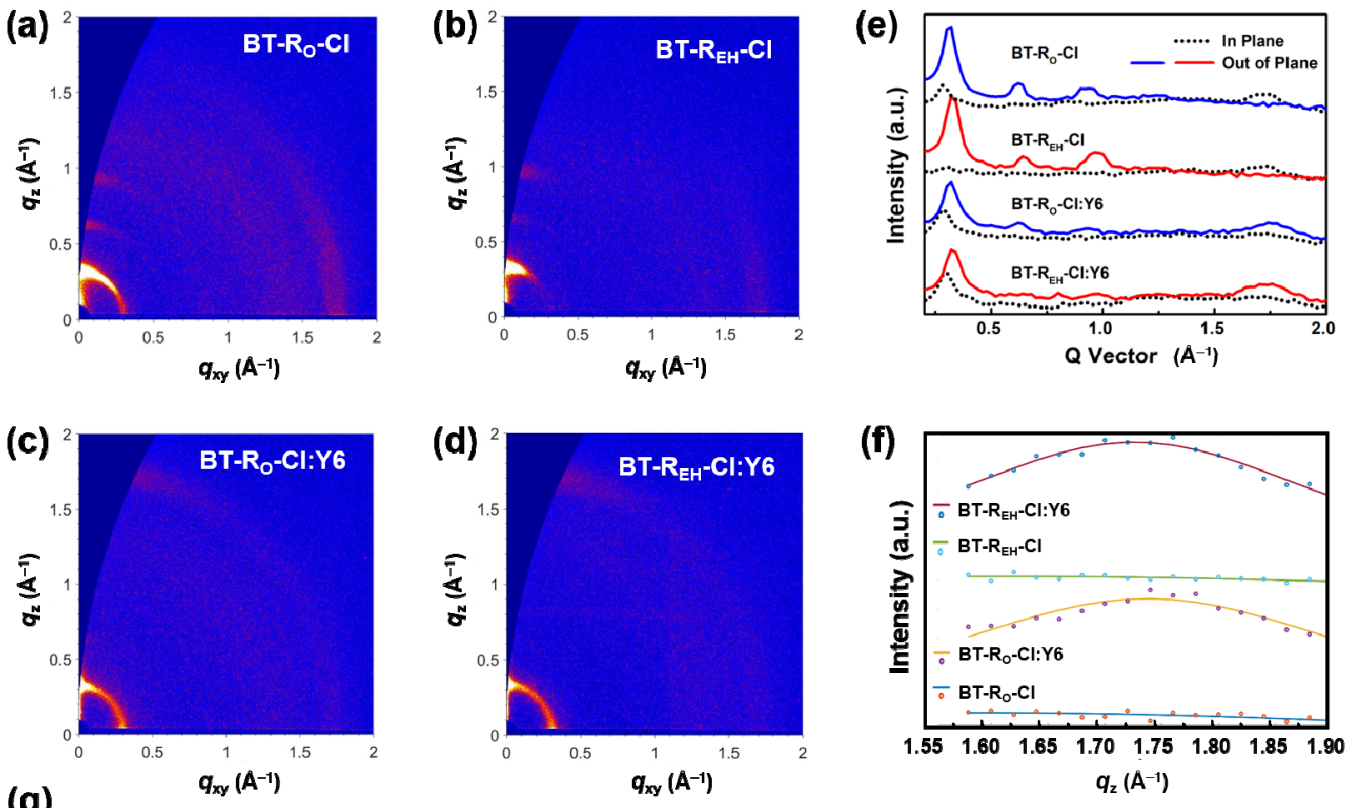

\begin{tabular}{|c|c|c|c|c|c|c|c|}
\hline \multirow[b]{2}{*}{ Plane } & \multirow[b]{2}{*}{ Samples } & \multirow{2}{*}{\multicolumn{2}{|c|}{$\begin{array}{l}\text { Direction } \\
\text { and Plane }\end{array}$}} & \multicolumn{4}{|c|}{$\pi-\pi$ Stacking } \\
\hline & & & & Location $\left(A^{-1}\right)$ & D-spacing (A) & CCL (Â) & $\begin{array}{l}\text { Relative Integrated } \\
\text { Intensity }\end{array}$ \\
\hline \multirow{2}{*}{ Out of Plane } & $\mathrm{BT}-\mathrm{R}_{\mathrm{o}}$-Cl:Y6 & $q_{z}$ & (010) & 1.74 & 3.60 & 12.02 & 1 \\
\hline & $B T-R_{E H^{-}}-\mathrm{Cl}: Y 6$ & $q_{z}$ & (010) & 1.73 & 3.64 & 12.40 & 1.1 \\
\hline
\end{tabular}

Figure 6. (a-d) GIWAXS patterns of pure and blended films; (e) in-plane (dotted lines) and out-ofplane (solid lines) line-cut profiles of the corresponding GIWAXS intensity profiles; (f) part of the intensity distribution and fitting curves corresponding to (010) diffractions in the $q_{\mathrm{z}}$ direction; and (g) the analysis data of (010) diffractions in the $q_{z}$ direction.

Moreover, in the out-of-plane direction, the (010) peaks of BT- $\mathrm{R}_{\mathrm{EH}}-\mathrm{Cl}$ :Y6 blended films were located at $q_{\mathrm{z}}=1.73 \AA^{-1}$ with the crystal coherence length (CCL) of $12.40 \mathrm{~nm}$, larger than that of BT- $\mathrm{R}_{\mathrm{O}}-\mathrm{Cl}: \mathrm{Y} 6$ film $\left(12.02 \mathrm{~nm}, q_{\mathrm{z}}=1.74 \AA^{-1}\right)$. As calculated by the integral area of (010) diffraction peaks in the $q_{\mathrm{z}}$ direction, the BT- $\mathrm{R}_{\mathrm{EH}}-\mathrm{Cl}$ :Y6 blended film showed a higher relative integrated intensity (1.1 times for BT- $\mathrm{R}_{\mathrm{O}}-\mathrm{Cl}$ :Y6 blended film (Figure $\left.6 \mathrm{~g}\right)$ ), indicating a higher crystallinity of the BT- $\mathrm{R}_{\mathrm{EH}}-\mathrm{Cl}: \mathrm{Y} 6$ blended system compared with the BT$\mathrm{R}_{\mathrm{O}}-\mathrm{Cl}$ :Y6 blended system, and displaying a tighter $\pi-\pi$ stacking in the mixed BT- $\mathrm{R}_{\mathrm{EH}}-\mathrm{Cl}: \mathrm{Y} 6$ system [31]. Because of the inferior solubility of planar fused-ring NFAs, solubilizing smallmolecule donors can promote a molecular match and relative crystallinity for a mixture of the active layer, in addition to further fine-tuning phase separation and morphology and providing a higher charge transport as well as efficiency for ASM OSC devices. 


\section{Conclusions}

Two small-molecular donors $\mathrm{BT}-\mathrm{R}_{\mathrm{O}}-\mathrm{Cl}$ and $\mathrm{BT}-\mathrm{R}_{\mathrm{EH}}-\mathrm{Cl}$ with isomeric terminal alkyl chains were conveniently synthesized. Despite changing only the terminal alkyl chains, disparities were observed in their physicochemical and photoelectric properties, such as absorption coefficient, solubility, thermal transition temperature, and crystallinity. When applied to ASM OSCs, BT- $\mathrm{R}_{\mathrm{EH}}-\mathrm{Cl}$ with branched terminal alkyl chains exhibited better phase-separation and more vibrant 3D charge transport channeling, and obtained higher and more balanced carrier mobilities with a high FF approaching $70 \%$, thus gaining an optimal efficiency of $13.90 \%$ for the BT- $\mathrm{R}_{\mathrm{EH}}-\mathrm{Cl}$ :Y6-based devices. This work not only enriched the highly efficient small-molecule donors, but also highlights how tiny but suitable alkyl chain engineering can fine-tune the phase-separation morphology, and may offer an alternative method for the optimal design of small-molecule materials for high-performance ASM OSCs.

Supplementary Materials: The following are available online at https:/ /www.mdpi.com/article/10 .3390/en14092505/s1: Materials Source; Material Characterizations; Device Fabrication and Testing; Carrier Mobility Measurement; Supplementary Figures; and Supplementary Tables.

Author Contributions: Synthesis, characterization, writing, and revising manuscript-H.C.; device fabrication and optimization-H.T. and D.H.; data analysis and curation-H.C., D.H., J.F., J.L., and Q.Y.; GIWAX testing-Y.X. and X.L.; discussion, supervision, and resources-Z.X., H.H., and S.L. All authors have read and agreed to the published version of the manuscript.

Funding: This research was funded by the Natural Science Foundation of Chongqing [grant number cstc2019jcyj-msxmX0400]; Youth Innovation Promotion Association Chinese Academy of Sciences [grant number 2020379]; and National Natural Science Foundation of China [grant number 62004129].

Institutional Review Board Statement: Not applicable.

Informed Consent Statement: Not applicable.

Data Availability Statement: Not applicable.

Conflicts of Interest: The authors declare no conflict of interest.

\section{References}

1. Inganäs, O. Organic photovoltaics over three decades. Adv. Mater. 2018, 30, 1800388. [CrossRef] [PubMed]

2. Wan, X.; Li, C.; Zhang, M.; Chen, Y. Acceptor-donor-acceptor type molecules for high performance organic photovoltaicschemistry and mechanism. Chem. Soc. Rev. 2020, 49, 2828-2842. [CrossRef] [PubMed]

3. Dey, S. Recent progress in molecular design of fused ring electron acceptors for organic solar cells. Small 2019, $15,1900134$. [CrossRef] [PubMed]

4. Zhao, F.; Wang, C.; Zhan, X. Morphology control in organic solar cells. Adv. Energy Mater. 2018, 8, 1703147. [CrossRef]

5. Liu, Q.; Jiang, Y.; Jin, K.; Qin, J.; Xu, J.; Li, W.; Xiong, J.; Liu, J.; Xiao, Z.; Sun, K.; et al. 18\% efficiency organic solar cells. Sci. Bull. 2020, 65, 272-275. [CrossRef]

6. Tang, H.; Yan, C.; Huang, J.; Kan, Z.; Xiao, Z.; Sun, K.; Li, G.; Lu, S. Benzodithiophene-based small-molecule donors for next-generation all-small-molecule organic photovoltaics. Matter 2020, 3, 1403-1432. [CrossRef]

7. Huo, Y.; Zhang, H.-L.; Zhan, X. Nonfullerene all-small-molecule organic solar cells. ACS Energy Lett. 2019, 4, 1241-1250. [CrossRef]

8. Zhou, Z.; Xu, S.; Song, J.; Jin, Y.; Yue, Q.; Qian, Y.; Liu, F.; Zhang, F.; Zhu, X. High-efficiency small-molecule ternary solar cells with a hierarchical morphology enabled by synergizing fullerene and non-fullerene acceptors. Nat. Energy 2018, 3, 952-959. [CrossRef]

9. Chen, H.; Hu, D.; Yang, Q.; Gao, J.; Fu, J.; Yang, K.; He, H.; Chen, S.; Kan, Z.; Duan, T.; et al. All-small-molecule organic solar cells with an ordered liquid crystalline donor. Joule 2019, 3, 3034-3047. [CrossRef]

10. Yue, Q.; Wu, H.; Zhou, Z.; Zhang, M.; Liu, F.; Zhu, X. 13.7\% efficiency small-molecule solar cells enabled by a combination of caterial and morphology optimization. Adv. Mater. 2019, 31, 1904283. [CrossRef] [PubMed]

11. Tang, H.; Chen, H.; Yan, C.; Huang, J.; Fong, P.W.K.; Lv, J.; Hu, D.; Singh, R.; Kumar, M.; Xiao, Z.; et al. Delicate morphology control triggers 14.7\% efficiency all-small-molecule organic solar cells. Adv. Energy Mater. 2020, 10, 2001076. [CrossRef]

12. Hu, D.; Yang, Q.; Chen, H.; Wobben, F.; Le Corre, V.M.; Singh, R.; Liu, T.; Ma, R.; Tang, H.; Anton Koster, L.J.; et al. 15.34\% efficiency all-small-molecule organic solar cells with improved fill factor enabled by a fullerene additive. Energy Environ. Sci. 2020, 13, 2134-2141. [CrossRef] 
13. Ge, J.; Xie, L.; Peng, R.; Fanady, B.; Huang, J.; Song, W.; Yan, T.; Zhang, W.; Ge, Z. 13.34\% efficiency non-fullerene all-smallmolecule organic solar cells enabled by modulating the crystallinity of donors via a fluorination strategy. Angew. Chem. Int. Ed. 2020, 59, 2808-2815. [CrossRef] [PubMed]

14. Zhou, R.; Jiang, Z.; Yang, C.; Yu, J.; Feng, J.; Abdullah Adil, M.; Deng, D.; Zou, W.; Zhang, J.; Lu, K.; et al. All-small-molecule organic solar cells with over $14 \%$ efficiency by optimizing hierarchical morphologies. Nat. Commun. 2019, 10, 5393. [CrossRef]

15. Gao, J.; Ge, J.; Peng, R.; Liu, C.; Cao, L.; Zhang, D.; Fanady, B.; Hong, L.; Zhou, E.; Ge, Z. Over 14\% efficiency nonfullerene all-small-molecule organic solar cells enabled by improving the ordering of molecular donor via side-chains engineering. J. Mater. Chem. A 2020, 8, 7405-7411. [CrossRef]

16. Qiu, B.; Chen, Z.; Qin, S.; Yao, J.; Huang, W.; Meng, L.; Zhu, H.; Yang, Y.M.; Zhang, Z.-G.; Li, Y. Highly efficient all-small-molecule organic solar cells with appropriate active layer morphology by side chain engineering of donor molecules and thermal annealing. Adv. Mater. 2020, 32, 1908373. [CrossRef] [PubMed]

17. Sun, R.; Wu, Y.; Guo, J.; Luo, Z.; Yang, C.; Min, J. High-efficiency all-small-molecule organic solar cells based on an organic molecule donor with an asymmetric thieno2,3-fbenzofuran unit. Sci. China Chem. 2020, 63, 1246-1255. [CrossRef]

18. Qin, J.; An, C.; Zhang, J.; Ma, K.; Yang, Y.; Zhang, T.; Li, S.; Xian, K.; Cui, Y.; Tang, Y.; et al. 15.3\% efficiency all-small-molecule organic solar cells enabled by symmetric phenyl substitution. Sci. China Mater. 2020, 63, 1142-1150. [CrossRef]

19. Jiang, K.; Wei, Q.; Lin Lai, J.Y.; Peng, Z.; Kim, H.K.; Yuan, J.; Ye, L.; Ade, H.; Zou, Y.; Yan, H. Alkyl chain tuning of small molecule acceptors for efficient organic solar cells. Joule 2019, 3, 3020-3033. [CrossRef]

20. Yiu, A.T.; Beaujuge, P.M.; Lee, O.P.; Woo, C.H.; Toney, M.F.; Freéchet, J.M.J. Side-chain tunability of furan-containing low-band-gap polymers provides control of structural order in efficient solar cells. J. Am. Chem. Soc. 2012, 134, 2180-2185. [CrossRef] [PubMed]

21. Fan, B.; Zhang, D.; Li, M.; Zhong, W.; Zeng, Z.; Ying, L.; Huang, F.; Cao, Y. Achieving over $16 \%$ efficiency for single-junction organic solar cells. Sci. China Chem. 2019, 62, 746-752. [CrossRef]

22. Yao, X.; Shao, W.; Xiang, X.; Xiao, W.-J.; Liang, L.; Zhao, F.-G.; Ling, J.; Lu, Z.; Li, J.; Li, W.-S. Side chain engineering on a small molecular semiconductor: Balance between solubility and performance by choosing proper positions for alkyl side chains. Organ. Electron. 2018, 61, 56-64. [CrossRef]

23. Más-Montoya, M.; Janssen, R.A.J. The effect of H- and J-Aggregation on the photophysical and photovoltaic properties of small thiophene-pyridine-DPP Molecules for bulk-heterojunction solar cells. Adv. Funct. Mater. 2017, 27, 1605779. [CrossRef]

24. Lee, C.J.; Mitchell, V.D.; White, J.; Jiao, X.; McNeill, C.R.; Subbiah, J.; Jones, D.J. Solubilizing core modifications on high-performing benzodithiophene-based molecular semiconductors and their influences on film nanostructure and photovoltaic performance. J. Mater. Chem. A 2019, 7, 6312-6326. [CrossRef]

25. Tang, H.; Xu, T.; Yan, C.; Gao, J.; Yin, H.; Lv, J.; Singh, R.; Kumar, M.; Duan, T.; Kan, Z.; et al. Donor derivative incorporation: An effective strategy toward high performance all-small-molecule ternary organic solar cells. Adv. Sci. 2019, 6, 1901613. [CrossRef] [PubMed]

26. Wang, K.; Lv, J.; Duan, T.; Li, Z.; Yang, Q.; Fu, J.; Meng, W.; Xu, T.; Xiao, Z.; Kan, Z.; et al. Simple near-infrared non-fullerene acceptors enable organic solar cells with $>9 \%$ efficiency. ACS Appl. Mater. Interfaces 2019, 11, 6717-6723. [CrossRef] [PubMed]

27. Liu, T.; Gao, W.; Zhang, G.; Zhang, L.; Xin, J.; Ma, W.; Yang, C.; Yan, H.; Zhan, C.; Yao, J. A high-performance non-fullerene acceptor compatible with polymers with different bandgaps for efficient organic solar cells. Sol. RRL 2019, 3, 1800376. [CrossRef]

28. Rivnay, J.; Mannsfeld, S.C.B.; Miller, C.E.; Salleo, A.; Toney, M.F. Quantitative determination of organic semiconductor microstructure from the molecular to device scale. Chem. Rev. 2012, 112, 5488-5519. [CrossRef]

29. Jung, M.; Yoon, Y.; Park, J.H.; Cha, W.; Kim, A.; Kang, J.; Gautam, S.; Seo, D.; Cho, J.H.; Kim, H.; et al. Nanoscopic management of molecular packing and orientation of small molecules by a combination of linear and branched alkyl side chains. ACS Nano 2014, 8, 6-5988. [CrossRef]

30. Sun, K.; Xiao, Z.; Lu, S.; Zajaczkowski, W.; Pisula, W.; Hanssen, E.; White, J.M.; Williamson, R.M.; Subbiah, J.; Ouyang, J.; et al. A molecular nematic liquid crystalline material for high-performance organic photovoltaics. Nat. Commun. 2015, 6, 6013. [CrossRef]

31. Jhuo, H.-J.; Liao, S.-H.; Li, Y.-L.; Yeh, P.-N.; Chen, S.-A.; Wu, W.-R.; Su, C.-J.; Lee, J.-J.; Yamada, N.L.; Jeng, U.-S. The novel additive 1-naphthalenethiol opens a new processing route to efficiency-enhanced polymer solar cells. Adv. Funct. Mater. 2016, 26, 3094-3104. [CrossRef] 